\title{
PEMBUATAN SOFTWARE SEBAGAI APLIKASI LINEAR SCHEDULING METHOD PADA PERENCANAAN PENJADWALAN PROYEK JALAN
}

\author{
Arthur Suryadharma ${ }^{1}$ dan Ratna S. Alifen ${ }^{2}$
}

\begin{abstract}
ABSTRAK: Proyek konstruksi jalan adalah contoh dari proyek linear, dimana terdiri aktivitas - aktivitas yang berulang dari unit yang satu ke unit berikut. Oleh karena itu tipe proyek ini butuh perencanaan penjadwalan yang tepat. Linear Scheduling Method (LSM) adalah teknik penjadwalan yang tepat untuk menjadwalkan unit - unit aktivitas proyek linear secara berkesinambungan sehingga terhindar dari idle time. Pada penelitian ini dilakukan pembuatan software LSM yang dapat menjaga kesinambungan kelompok kerja, disamping itu dapat menjadwalkan aktivitas - aktivitas agar terjadwal berdasarkan urutan yang ditentukan. Studi kasus proyek jalan digunakan pada penelitian ini untuk menguji software yang dibuat. Pembuatan software LSM menggunakan bantuan Visual Basic Software pada Microsoft Excel. Software yang diimplementasi pada proyek jalan menunjukkan kemampuan software yang dibuat untuk menghasilkan durasi proyek tanpa adanya idle time pada perpindahan kelompok kerja dan menjaga hubungan ketergantungan antar aktivitas.
\end{abstract}

Kata kunci: proyek linear, linear scheduling method, idle time.

ABSTRACT: Road construction project is good example of linear project that consist of linear activities where the same unit is repeated several times. Hence, these projects require appropriate schedule. Linear Scheduling Method (LSM) is well suited for scheduling linear activities by maintaining crew movement from one unit to another without idle time. This research develops a LSM software that be able to maintain crew movement continuity while scheduling activities based on interdependencies relationship among activities. Case study of road construction project is used to test the performance of the software. This LSM software development uses Visual Basic Software on Microsoft Excel. The results of this software which implemented in road construction project, showing its ability to generate project duration without idle time on crew movement and maintaining interdependencies relationship among activities.

Keywords: linear projects, linear scheduling method, idle time.

\section{PENDAHULUAN}

Proyek linear identik dengan proyek yang pekerjaannya berulang dari unit ke unit. Proyek konstruksi linear seperti proyek jalan, perpipaan, perumahan dan bangunan bertingkat mendominasi industri proyek konstruksi, oleh karena itu penjadwalan yang tepat untuk tipe proyek ini sangat krusial. Metode penjadwalan akan efektif bila digunakan berdasarkan karakteristik masing - masing proyek. Metode penjadwalan konvensional seperti Critical Path Method (CPM) bukan metode yang tepat untuk digunakan pada proyek konstruksi linear karena dapat menyebabkan network penjadwalan menjadi makin kompleks dan

\footnotetext{
1 Mahasiswa Progam Studi Magister Teknik Sipil Universitas Kristen Petra, arthur.suryadharma@gmail.com

2 Dosen Program Studi Magister Teknik Sipil Universitas Kristen Petra, alifrat@petra.ac.id
} 
ketidakmampuan menjadwalkan kelompok kerja untuk bekerja secara berkesinambungan dari unit ke unit suatu aktivitas pekerjaan (Zolfaghar, Afshar, \& Abbasnia, 2014). Sebaliknya Linear Scheduling Method (LSM) merupakan metode yang tepat untuk diterapkan pada proyek konstruksi linear karena dapat menjaga kesinambungan perpindahan kelompok kerja dari unit ke unit aktivitas.

Pada penelitian ini dilakukan pembuatan software LSM yang dapat menjaga kesinambungan perpindahan kelompok kerja dari unit ke unit aktivitas tanpa adanya idle time, di samping itu dapat menjadwalkan aktivitas - aktivitas pada LSM agar terjadwal berdasarkan urutan yang ditentukan. Software ini menggunakan studi kasus proyek jalan untuk menguji kemampuan software yang dibuat. Software yang dibuat diharapkan dapat digunakan oleh kontraktor pada proyek linear di waktu mendatang.

\section{LANDASAN TEORI}

LSM merupakan metode penjadwalan yang cocok digunakan pada proyek dengan karakteristik aktivitas yang linear atau berulang. Tujuan dari LSM adalah untuk merencanakan dan menjadwalkan unit - unit aktivitas proyek agar berlangsung secara berkesinambungan dan menghindari idle time pada sumber daya yang digunakan (Hyari \& El-Rayes, 2006). Format dasar dari LSM adalah time diplotkan pada sumbu horisontal dan unit number pada sumbu vertikal (Gambar 1). Lebar bar pada suatu unit aktivitas menggambarkan durasi aktivitas pada unit tersebut, sedangkan titik awal tiap bar merupakan start unit aktivitas dan titik akhir tiap bar merupakan finish unit aktivitas (Ammar, 2013). Suatu aktivitas dapat dikerjakan oleh 1 crew (kelompok kerja) maupun lebih. Perpindahan kelompok kerja dari unit ke unit berikut harus dijadwalkan secara berkesinambungan. Hubungan antar aktivitas dalam LSM berupa finish to start dengan lag maupun tanpa lag.

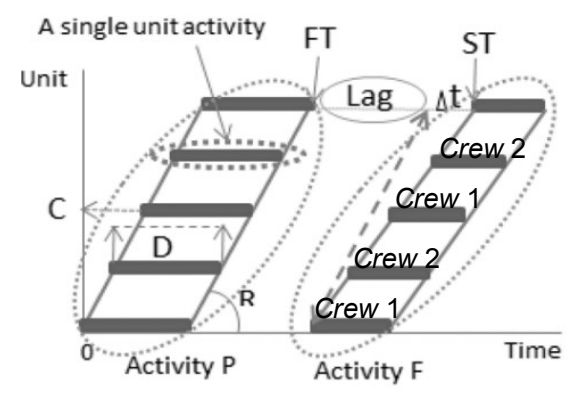

Gambar 1. Konsep LSM (Shuh, Lin, Lin, \& Wang, 2013)

Banyak penelitian yang telah dilakukan dalam menyempurnakan konsep LSM dalam beberapa tahun terakhir. Sebagian besar menyimpulkan bahwa kesinambungan perpindahan kelompok kerja merupakan faktor krusial dalam menjadwalkan LSM karena menggambarkan efisiensi sumber daya yang digunakan (Agrama, 2011; Ammar, 2013; Arditi, Tokdemir, \& Suh, 2002; Hafez, 2004; Iswanto, 2006). Namun selain itu, beberapa penelitian menyebutkan kelemahan LSM dalam menjadwalkan aktivitas berdasarkan hubungan ketergantungannya (Ammar, 2013; Arditi et al., 2002; Hafez, 2004). Dari studi literatur yang dilakukan, maka kedua faktor tersebut dijadikan variabel dalam pembuatan software LSM. 


\section{PEMBUATAN SOFTWARE LSM}

Software LSM dibuat mengunakan bantuan Visual Basic Application pada Microsoft Excel. Software LSM terdiri dari 3 tahap utama, yaitu input, proses dan output. Pada tahap input beberapa data yang dimasukkan terdiri dari: data umum perencanaan proyek, informasi hubungan ketergantungan aktivitas (predecessor dan lag tiap aktivitas), durasi aktivitas pada tiap section proyek dan jumlah kelompok kerja tiap aktivitas. Sedangkan output software yang dihasilkan adalah: alokasi kelompok kerja tiap aktivitas, start dan finish aktivitas tiap section dan total durasi proyek. Proses perhitungan dalam software LSM terdiri dari 2 tahapan, yaitu tahapan dalam alokasi kelompok kerja pada tiap aktivitas dan tahapan perhitungan start dan finish tiap aktivitas (Gambar 2).

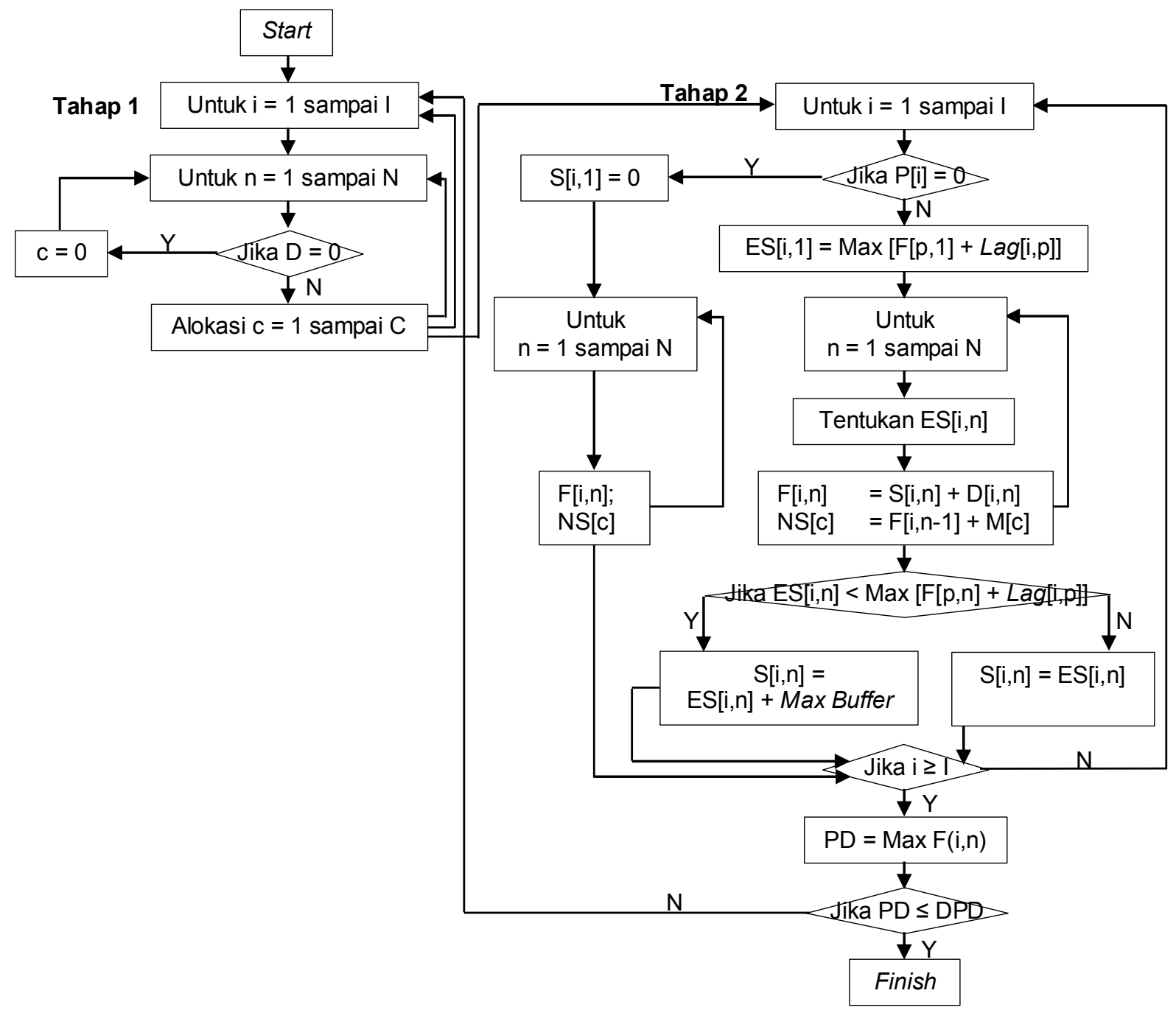

Gambar 2. Bagan Alir Algoritma Penjadwalan LSM

Pada tahap pertama, kelompok kerja (c) dialokasi pada tiap section aktivitas yang memiliki durasi $(\mathrm{D} \neq 0)$. Sedangkan pada tahap kedua, untuk menentukan waktu start dan finish aktivitas tiap section, perlu ditentukan terlebih dahulu aktivitas pertama pekerjaan. Aktivitas pertama diidentifikasi sebagai aktivitas yang tidak memiliki predecessor $(P[i]=0)$. Start awal aktivitas pertama pada section awal dinyatakan pada Persamaan 1. Berikutnya untuk finish tiap section aktivitas dihitung dengan menggunakan Persamaan 2. Sedangkan dalam menentukan start aktivitas tiap section berikut oleh kelompok kerja c adalah dengan 
menggunakan Persamaan 3. Perpindahan kelompok kerja dianggap sama dengan nol $(\mathrm{M}[\mathrm{C}]$ $=0)$.

$S[i, 1]=0$

$F[i, n]=S[i, n]+D[i, n]$

$N S[c]=F[i, n-1]+M[c]$.

Berikutnya untuk menentukan titik start aktivitas yang memiliki predecessor ( $P[i] \neq 0)$, adalah dengan menghitung early start aktivitas terlebih dahulu. Early start aktivitas ditentukan dengan menetapkan nilai maksimum dari finish awal predecessor ditambah lag predecessor sebagai acuan start awal aktivitas atau dapat dihitung dengan Persamaan 4. Setelah acuan awal start aktivitas diketahui, maka kemudian dihitung start dan finish tiap sectionnya (ES[i,n]) dengan menggunakan Persamaan 2 dan 3. Setelah diperoleh nilai early start dari aktivitas i (ES[i,n]), proses berikutnya adalah membandingkan early start aktivitas i tersebut dengan maksimum finish aktivitas predecessor yang ditambah lag predecessor. Apabila nilai early start lebih kecil dari nilai maksimum finish aktivitas predecessor dan lag predecessor, hal ini menandakan terjadi interfensi antar aktivitas i dan aktivitas predecessor. Untuk menghindari terjadinya interfensi antar aktivitas, adalah memberi buffer antar aktivitas i dan predecessomya. Buffer adalah selisih antara early start aktivitas i dan finish aktivitas predecessor ditambah lag (Persamaan 5). Buffer tiap section yang diperoleh dari Persamaan 5 kemudian diambil yang maksimum sebagai buffer antara aktivitas i dan aktivitas predecessor. Sehingga start aktivitas i adalah early start aktivitas i ditambah maksimum buffer (Persamaan 6). Sebaliknya, apabila nilai early start lebih besar dari nilai maksimum finish aktivitas predecessor dan lag predecessor menunjukkan tidak ada interfensi aktivitas yang terjadi. Pada kondisi ini, nilai start aktivitas i yang dipakai adalah sama dengan early start aktivitas i (Persamaan 7).

$$
\begin{aligned}
& E S[i, 1]=\operatorname{Max}[F[p, 1]+\operatorname{Lag}[i, p] \text {. } \\
& \text { Buffer }=E S[i, n]-\operatorname{Max}[F[p, n]+\operatorname{Lag}[i, p]] \\
& S[i, n]=E S[i, n]+\text { Max Buffer } \\
& \mathrm{S}[\mathrm{i}, \mathrm{n}]=\mathrm{ES}[\mathrm{i}, \mathrm{n}]
\end{aligned}
$$

Setelah proses perhitungan waktu start dan finish tiap section pada seluruh aktivitas selesai maka proses terakhir adalah menentukan durasi proyek, yang dihitung dengan menggunakan Persamaan 8. Durasi proyek yang dihasilkan software LSM kemudian dibandingkan dengan jangka waktu proyek pada data perencanaan penjadwalan LSM yang menjadi target waktu penyelesaian proyek (DPD).

$P D=\operatorname{Max} F[i, n]$

\section{PENERAPAN SOFTWARE LSM PADA PROYEK KONSTRUKSI JALAN}

Studi kasus yang digunakan dalam penelitian ini untuk menguji software yang dibuat adalah proyek konstruksi jalan Nangaroro - Maunori yang terletak di Provinsi Nusa Tenggara Timur, dengan panjang $2,3 \mathrm{~km}$ dan dibagi menjadi 23 section pekerjaan, dengan panjang tiap section adalah $100 \mathrm{~m}$. 


\subsection{Input Software LSM}

Variabel - variabel yang diinput pada software LSM ditandai dengan kotak berwarna putih, sedangkan output software ditandai dengan kotak berwarna abu - abu. Pada Gambar 4, informasi yang diinput berupa informasi umum proyek, sedangkan jumlah predecessor maksimum adalah jumlah predecessor terbanyak dari suatu aktivitas (Gambar 3). Berikutnya dari CPM Gambar 3, maka data predecessor dan lag tiap aktivitas diinput pada Tabel 1.

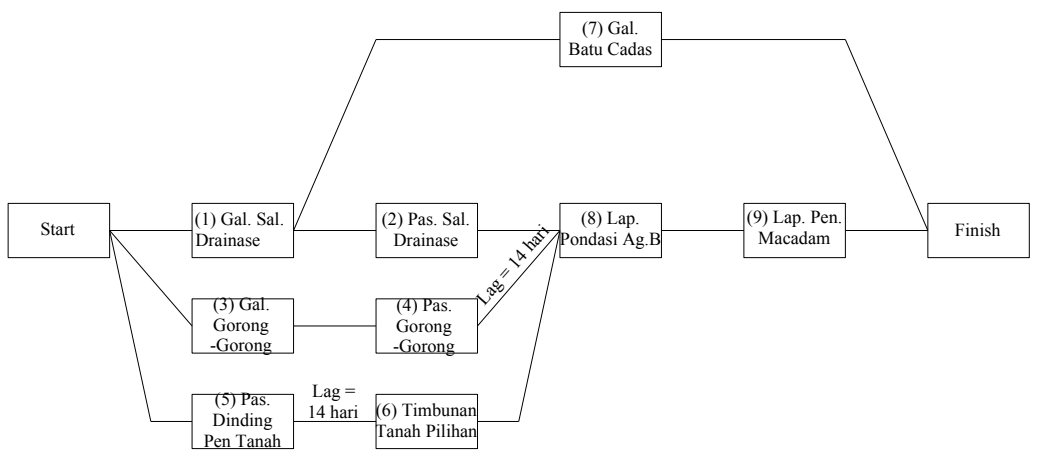

Gambar 3. Urutan Aktivitas Pekerjaan Konstruksi Jalan

\begin{tabular}{|c|c|c|}
\hline & DATA PERE & N PENJADWALAN LSM \\
\hline Nama Proyek & $=$ & Peningkatan Jalan Nangaroro - Maunura - Maunori \\
\hline Lokasi Proyek & $=$ & Nangaroro \\
\hline Kontraktor & $=$ & CV. Anugerah Cipta Jaya \\
\hline Jangka Waktu Pekerjaan & $=$ & hari \\
\hline Jam Kerja Efektif per Hari & $=$ & jam \\
\hline Jumlah Aktivitas & $=$ & aktivitas \\
\hline Panjang Jalan & $=$ & 2300 \\
\hline Panjang tiap Section & $=$ & 100 \\
\hline Jumlah Section / Unit Pekerjaan & $=$ & section \\
\hline Jumlah Predecessor Maksimum & $=$ & predecessor \\
\hline
\end{tabular}

Gambar 4. Data Perencanaan Penjadwalan LSM

Tabel 1. Tabel Hubungan Ketergantungan Aktivitas

\begin{tabular}{|c|l|c|c|c|c|c|c|}
\hline \multirow{2}{*}{ No. Aktivitas (i) } & \multicolumn{5}{c|}{ Predecessor (P) } \\
\cline { 3 - 8 } & & $\mathrm{P}(1)$ & $\operatorname{Lag}(1)$ & $\mathrm{P}(2)$ & $\operatorname{Lag}(2)$ & $\mathrm{P}(3)$ & $\operatorname{Lag}(3)$ \\
\hline 1 & Galian Saluran Drainase & - & - & - & - & - & - \\
\hline 2 & Pasangan Saluran Drainase & 1 & 0 & - & - & - & - \\
\hline 3 & Galian Gorong - Gorong & - & - & - & - & - & - \\
\hline 4 & Pasangan Gorong - Gorong & 3 & 0 & - & - & - & - \\
\hline 5 & Pasangan Dinding Penahan Tanah & - & - & - & - & - & - \\
\hline 6 & Timbunan Tanah Pilihan & 5 & 14 & - & - & - & - \\
\hline 7 & Galian Batu Cadas & 1 & 0 & - & - & - & - \\
\hline 8 & Lapis Pondasi Agregat Kelas B & 2 & 0 & 6 & 0 & 4 & 14 \\
\hline 9 & Lapis Permukaan Penetrasi Macadam & 8 & 0 & - & - & - & - \\
\hline
\end{tabular}




\subsection{Output Software LSM}

Setelah menginput variabel - variable di atas, tahap berikut adalah menginput durasi aktivitas tiap section aktivitas dan jumlah kelompok kerja tiap aktivitas untuk menghasilkan output berupa alokasi kelompok kerja, start dan finish aktivitas tiap section dan total durasi proyek (Tabel 2). Total durasi proyek yang dihasilkan untuk proyek konstruksi jalan ini adalah sebesar 83 hari.

Tabel 2. Output Software LSM

\begin{tabular}{|c|c|c|c|c|c|c|c|c|c|c|c|c|c|c|c|c|c|c|c|c|}
\hline \multirow{3}{*}{ Section } & \multicolumn{4}{|c|}{ (1) Galian Saluran Drainase } & \multicolumn{4}{|c|}{ (2) Pasangan Saluran Drainase } & \multicolumn{4}{|c|}{ (3) Galian Gorong - Gorong } & \multicolumn{4}{|c|}{ (4) Pasangan Gorong - Gorong } & \multicolumn{4}{|c|}{ (5) Pasangan Dinding Penahan Tanah } \\
\hline & \multicolumn{3}{|c|}{ Jumlah Kelompok Kerja $=$} & \multirow{2}{*}{$\begin{array}{c}1 \\
\text { Finish }\end{array}$} & \multicolumn{3}{|c|}{ Jumlah Kelompok Kerja = } & \multirow{2}{*}{$\begin{array}{c}2 \\
\text { Finish }\end{array}$} & \multicolumn{3}{|c|}{ Jumlah Kelompok Kerja $=$} & \multirow{2}{*}{$\frac{1}{\text { Finish }}$} & \multicolumn{3}{|c|}{ Jumlah Kelompok Kerja = } & \multirow{2}{*}{$\begin{array}{c}1 \\
\text { Finish }\end{array}$} & \multicolumn{3}{|c|}{ Jumlah Kelompok Kerja $=$} & \multirow{2}{*}{$\begin{array}{c}2 \\
\text { Finish }\end{array}$} \\
\hline & Durasi & \begin{tabular}{|c|} 
Alokasi \\
Kelompok \\
Kerja \\
\end{tabular} & Start & & Durasi & \begin{tabular}{|c|} 
Alokasi \\
Kelompok \\
Kerja \\
\end{tabular} & Start & & Durasi & \begin{tabular}{|c|} 
Alokasi \\
Kelompok \\
Kerja \\
\end{tabular} & Start & & Durasi & \begin{tabular}{|c|} 
Alokasi \\
Kelompok \\
Kerja \\
\end{tabular} & Start & & Durasi & $\begin{array}{c}\text { Alokasi } \\
\text { Kelompok } \\
\text { Kerja }\end{array}$ & Start & \\
\hline 1 & 1.00 & 1 & 0.00 & 1.00 & 6.00 & 1 & 2.00 & 8.00 & 0.00 & 0 & 0.00 & 0.00 & 0.00 & \begin{tabular}{|l|l}
0 \\
\end{tabular} & 1.00 & 1.00 & 0.00 & 0 & 0.00 & 0.00 \\
\hline 2 & 1.00 & 1 & 1.00 & 2.00 & 6.00 & 2 & 2.00 & 8.00 & 1.00 & 1 & 0.00 & 1.00 & 2.00 & 1 & 1.00 & 3.00 & 7.00 & 1 & 0.00 & 7.00 \\
\hline 3 & 1.00 & 1 & 2.00 & 3.00 & 6.00 & 1 & 8.00 & 14.00 & 0.00 & 0 & 1.00 & 1.00 & 0.00 & 0 & 3.00 & 3.00 & 8.00 & 2 & 0.00 & 8.00 \\
\hline 4 & 1.00 & 1 & 3.00 & 4.00 & 6.00 & 2 & 8.00 & 14.00 & 0.00 & 0 & 1.00 & 1.00 & 0.00 & 0 & 3.00 & 3.00 & 9.00 & 1 & 7.00 & 16.00 \\
\hline 5 & 1.00 & 1 & 4.00 & 5.00 & 6.00 & 1 & 14.00 & 20.00 & 0.00 & 0 & 1.00 & 1.00 & 0.00 & 0 & 3.00 & 3.00 & 9.00 & 2 & 8.00 & 17.00 \\
\hline 6 & 1.00 & 1 & 5.00 & 6.00 & 6.00 & 2 & 14.00 & 20.00 & 0.00 & 0 & 1.00 & 1.00 & 0.00 & 0 & 3.00 & 3.00 & 0.00 & 0 & 17.00 & 17.00 \\
\hline 7 & 1.00 & 1 & 6.00 & 7.00 & 6.00 & 1 & 20.00 & 26.00 & 0.00 & 0 & 1.00 & 1.00 & 0.00 & 0 & 3.00 & 3.00 & 0.00 & 0 & 17.00 & 17.00 \\
\hline 8 & 1.00 & 1 & 7.00 & 8.00 & 6.00 & 2 & 20.00 & 26.00 & 0.00 & 0 & 1.00 & 1.00 & 0.00 & 0 & 3.00 & 3.00 & 0.00 & 0 & 17.00 & 17.00 \\
\hline 9 & 1.00 & 1 & 8.00 & 9.00 & 6.00 & 1 & 26.00 & 32.00 & 0.00 & 0 & 1.00 & 1.00 & 0.00 & 0 & 3.00 & 3.00 & 9.00 & 1 & 16.00 & 25.00 \\
\hline 10 & 1.00 & 1 & 9.00 & 10.00 & 6.00 & 2 & 26.00 & 32.00 & 0.00 & 0 & 1.00 & 1.00 & 0.00 & 0 & 3.00 & 3.00 & 0.00 & 0 & 25.00 & 25.00 \\
\hline 11 & 1.00 & 1 & 10.00 & 11.00 & 6.00 & 1 & 32.00 & 38.00 & 1.00 & 1 & 1.00 & 2.00 & 2.00 & 1 & 3.00 & 5.00 & 9.00 & 2 & 17.00 & 26.00 \\
\hline 12 & 1.00 & 1 & 11.00 & 12.00 & 6.00 & 2 & 32.00 & 38.00 & 0.00 & 0 & 2.00 & 2.00 & 0.00 & 0 & 5.00 & 5.00 & 0.00 & 0 & 26.00 & 26.00 \\
\hline 13 & 1.00 & 1 & 12.00 & 13.00 & 6.00 & 1 & 38.00 & 44.00 & 0.00 & 0 & 2.00 & 2.00 & 0.00 & 0 & 5.00 & 5.00 & 0.00 & 0 & 26.00 & 26.00 \\
\hline 14 & 1.00 & 1 & 13.00 & 14.00 & 6.00 & 2 & 38.00 & 44.00 & 0.00 & 0 & 2.00 & 2.00 & 0.00 & 0 & 5.00 & 5.00 & 0.00 & 0 & 26.00 & 26.00 \\
\hline 15 & 1.00 & 1 & 14.00 & 15.00 & 6.00 & 1 & 44.00 & 50.00 & 0.00 & 0 & 2.00 & 2.00 & 0.00 & 0 & 5.00 & 5.00 & 0.00 & 0 & 26.00 & 26.00 \\
\hline 16 & 1.00 & 1 & 15.00 & 16.00 & 6.00 & 2 & 44.00 & 50.00 & 0.00 & 0 & 2.00 & 2.00 & 0.00 & 0 & 5.00 & 5.00 & 0.00 & 0 & 26.00 & 26.00 \\
\hline 17 & 1.00 & 1 & 16.00 & 17.00 & 6.00 & 1 & 50.00 & 56.00 & 0.00 & 0 & 2.00 & 2.00 & 0.00 & 0 & 5.00 & 5.00 & 0.00 & 0 & 26.00 & 26.00 \\
\hline 18 & 1.00 & 1 & 17.00 & 18.00 & 6.00 & 2 & 50.00 & 56.00 & 0.00 & 0 & 2.00 & 2.00 & 0.00 & 0 & 5.00 & 5.00 & 0.00 & 0 & 26.00 & 26.00 \\
\hline 19 & 1.00 & 1 & 18.00 & 19.00 & 6.00 & 1 & 56.00 & 62.00 & 0.00 & 0 & 2.00 & 2.00 & 0.00 & 0 & 5.00 & 5.00 & 0.00 & 0 & 26.00 & 26.00 \\
\hline 20 & 0.00 & 0 & 19.00 & 19.00 & 0.00 & 0 & 62.00 & 62.00 & 0.00 & 0 & 2.00 & 2.00 & 0.00 & 0 & 5.00 & 5.00 & 0.00 & 0 & 26.00 & 26.00 \\
\hline 21 & 0.00 & 0 & 19.00 & 19.00 & 0.00 & 0 & 62.00 & 62.00 & 0.00 & 0 & 2.00 & 2.00 & 0.00 & 0 & 5.00 & 5.00 & 10.00 & 1 & 25.00 & 35.00 \\
\hline 22 & 0.00 & 0 & 19.00 & 19.00 & 0.00 & 0 & 62.00 & 62.00 & 0.00 & 0 & 2.00 & 2.00 & 0.00 & 0 & 5.00 & 5.00 & 0.00 & 0 & 35.00 & 35.00 \\
\hline 23 & 0.00 & 0 & 19.00 & 19.00 & 0.00 & 0 & 62.00 & 62.00 & 0.00 & 0 & 2.00 & 2.00 & 0.00 & 0 & 5.00 & 5.00 & 9.00 & 2 & 26.00 & 35.00 \\
\hline
\end{tabular}

Tabel 2. (Lanjutan)

\begin{tabular}{|c|c|c|c|c|c|c|c|c|c|c|c|c|c|c|c|c|}
\hline \multirow{3}{*}{ Section } & \multicolumn{4}{|c|}{ (6) Timbunan Tanah Pilihan } & \multicolumn{4}{|c|}{ (7) Galian Batu Cadas } & \multicolumn{4}{|c|}{ (8) Lapis Pondasi Agregat Kelas B } & \multicolumn{4}{|c|}{ (9) Lapis Permukaan Penetrasi Macadam } \\
\hline & \multicolumn{3}{|c|}{ Jumlah Kelompok Kerja $=$} & \multirow{2}{*}{$\begin{array}{c}1 \\
\text { Finish }\end{array}$} & \multicolumn{3}{|c|}{ Jumlah Kelompok Kerja $=$} & \multirow{2}{*}{$\begin{array}{c}1 \\
\text { Finish }\end{array}$} & \multicolumn{3}{|c|}{ Jumlah Kelompok Kerja = } & \multirow{2}{*}{$\begin{array}{c}1 \\
\text { Finish }\end{array}$} & \multicolumn{3}{|c|}{ Jumlah Kelompok Kerja $=$} & \multirow{2}{*}{$\begin{array}{c}1 \\
\text { Finish }\end{array}$} \\
\hline & Durasi & \begin{tabular}{|c|c|} 
Alokasi \\
Kelompo \\
k Kerja \\
\end{tabular} & Start & & Durasi & \begin{tabular}{|c|} 
Alokasi \\
Kelompok \\
Kerja \\
\end{tabular} & Start & & Durasi & \begin{tabular}{|c|} 
Alokasi \\
Kelompok \\
Kerja \\
\end{tabular} & Start & & Durasi & \begin{tabular}{|c|} 
Alokasi \\
Kelompok \\
Kerja \\
\end{tabular} & Start & \\
\hline 1 & 0.00 & 0 & 43.00 & 43.00 & 0.00 & 0 & 19.00 & 19.00 & 1.00 & 1 & 44.00 & 45.00 & 2.00 & 1 & 45.00 & 47.00 \\
\hline 2 & 1.00 & 1 & 43.00 & 44.00 & 0.00 & 0 & 19.00 & 19.00 & 1.00 & 1 & 45.00 & 46.00 & 2.00 & 1 & 47.00 & 49.00 \\
\hline 3 & 1.00 & 1 & 44.00 & 45.00 & 0.00 & 0 & 19.00 & 19.00 & 1.00 & 1 & 46.00 & 47.00 & 2.00 & 1 & 49.00 & 51.00 \\
\hline 4 & 1.00 & 1 & 45.00 & 46.00 & 0.00 & 0 & 19.00 & 19.00 & 1.00 & 1 & 47.00 & 48.00 & 2.00 & 1 & 51.00 & 53.00 \\
\hline 5 & 1.00 & 1 & 46.00 & 47.00 & 0.00 & 0 & 19.00 & 19.00 & 1.00 & 1 & 48.00 & 49.00 & 2.00 & 1 & 53.00 & 55.00 \\
\hline 6 & 0.00 & 0 & 47.00 & 47.00 & 0.00 & 0 & 19.00 & 19.00 & 1.00 & 1 & 49.00 & 50.00 & 2.00 & 1 & 55.00 & 57.00 \\
\hline 7 & 0.00 & 0 & 47.00 & 47.00 & 0.00 & 0 & 19.00 & 19.00 & 1.00 & 1 & 50.00 & 51.00 & 2.00 & 1 & 57.00 & $\begin{array}{l}59.00 \\
\end{array}$ \\
\hline 8 & 0.00 & 0 & 47.00 & 47.00 & 0.00 & 0 & 19.00 & 19.00 & 1.00 & 1 & 51.00 & 52.00 & 2.00 & 1 & 59.00 & 61.00 \\
\hline 9 & 1.00 & 1 & 47.00 & 48.00 & 0.00 & 0 & 19.00 & 19.00 & 1.00 & 1 & 52.00 & 53.00 & 2.00 & 1 & 61.00 & 63.00 \\
\hline 10 & 0.00 & 0 & 48.00 & 48.00 & 0.00 & 0 & 19.00 & 19.00 & 1.00 & 1 & 53.00 & 54.00 & 2.00 & 1 & 63.00 & 65.00 \\
\hline 11 & 1.00 & 1 & 48.00 & 49.00 & 0.00 & 0 & 19.00 & 19.00 & 1.00 & 1 & 54.00 & 55.00 & 2.00 & 1 & 65.00 & 67.00 \\
\hline 12 & 0.00 & 0 & 49.00 & 49.00 & 0.00 & 0 & 19.00 & 19.00 & 1.00 & 1 & 55.00 & 56.00 & 2.00 & 1 & 67.00 & 69.00 \\
\hline 13 & 0.00 & 0 & 49.00 & 49.00 & 0.00 & 0 & 19.00 & 19.00 & 1.00 & 1 & 56.00 & 57.00 & 2.00 & 1 & 69.00 & 71.00 \\
\hline 14 & 0.00 & 0 & 49.00 & 49.00 & 0.00 & 0 & 19.00 & 19.00 & 1.00 & 1 & 57.00 & 58.00 & 2.00 & 1 & 71.00 & 73.00 \\
\hline 15 & 0.00 & 0 & 49.00 & 49.00 & 0.00 & 0 & 19.00 & 19.00 & 1.00 & 1 & 58.00 & 59.00 & 2.00 & 1 & 73.00 & 75.00 \\
\hline 16 & 0.00 & 0 & 49.00 & 49.00 & 0.00 & 0 & 19.00 & 19.00 & 1.00 & 1 & 59.00 & 60.00 & 2.00 & 1 & 75.00 & 77.00 \\
\hline 17 & 0.00 & 0 & 49.00 & 49.00 & 0.00 & 0 & 19.00 & 19.00 & 1.00 & 1 & 60.00 & 61.00 & 2.00 & 1 & 77.00 & 79.00 \\
\hline 18 & 0.00 & 0 & 49.00 & 49.00 & 0.00 & 0 & 19.00 & 19.00 & 1.00 & 1 & 61.00 & 62.00 & 2.00 & 1 & 79.00 & 81.00 \\
\hline 19 & 0.00 & 0 & 49.00 & 49.00 & 0.00 & 0 & 19.00 & 19.00 & 1.00 & 1 & 62.00 & 63.00 & 2.00 & 1 & 81.00 & 83.00 \\
\hline 20 & 0.00 & 0 & 49.00 & 49.00 & 5.00 & 1 & 19.00 & 24.00 & 0.00 & 0 & 63.00 & 63.00 & 0.00 & 0 & 83.00 & 83.00 \\
\hline 21 & 1.00 & 1 & 49.00 & 50.00 & 11.00 & 1 & 24.00 & 35.00 & 0.00 & 0 & 63.00 & 63.00 & 0.00 & 0 & 83.00 & 83.00 \\
\hline 22 & 0.00 & 0 & 50.00 & 50.00 & 10.00 & 1 & 35.00 & 45.00 & 0.00 & 0 & 63.00 & 63.00 & 0.00 & 0 & 83.00 & 83.00 \\
\hline 23 & 1.00 & 1 & 50.00 & 51.00 & 12.00 & 1 & 45.00 & 57.00 & 0.00 & 0 & 63.00 & 63.00 & 0.00 & 0 & 83.00 & 83.00 \\
\hline
\end{tabular}




\subsection{Grafik LSM}

Grafik LSM merupakan grafik informatif yang menampilkan informasi penjadwalan LSM dalam 2 dimensi, yaitu dimensi waktu (hari) pada sumbu $X$ dan dimensi lokasi (section) pada sumbu Y. Untuk menjadikan grafik mudah dibaca, maka grafik LSM ditampilkan berdasarkan tiap individual path yang ada pada network CPM. Path 2 (Gambar 5) merupakan jalur kritis dimana bila terjadi keterlambatan pada salah satu aktivitas yang berada di dalamnya, maka akan menyebabkan molornya total durasi proyek.

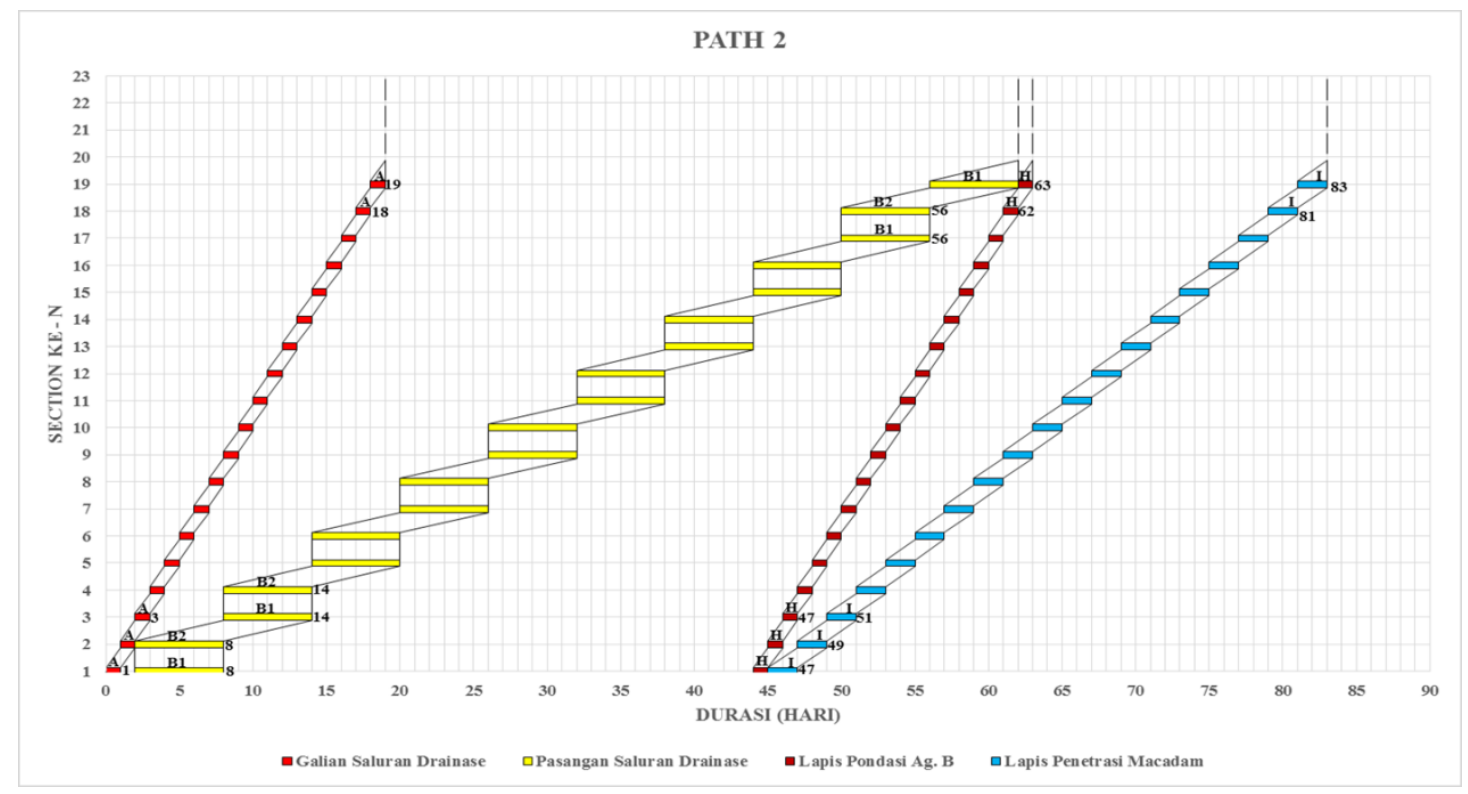

Gambar 5. Path 2

\section{KESIMPULAN}

- Perencanaan penjadwalan proyek konstruksi jalan menggunakan software LSM yang dibuat, menghasilkan total durasi proyek sebesar 83 hari kerja.

- Output dari software LSM menunjukkan perpindahan kelompok dalam suatu aktivitas berlangsung berkesinambungan, tanpa idle time pada perpindahan kelompok kerja.

- Software LSM yang dibuat memungkinkan perencana dalam mengatur urutan aktivitas proyek dengan cara menginput informasi yang ada pada network penjadwalan CPM ke dalam tabel hubungan ketergantungan aktivitas.

- Durasi yang dapat diinput pada tiap section aktivitas memungkinkan user dalam mengkombinasikan aktivitas linear yang tipikal dan non tipikal pada software LSM ini.

- Penerapan software LSM pada studi kasus proyek konstruksi jalan menunjukkan bahwa software ini dapat digunakan dalam perencanaan penjadwalan proyek yang sifatnya linear di waktu mendatang (khususnya proyek konstruksi jalan).

\section{SARAN}

- Pada penelitian selanjutnya diharapkan mempertimbangkan faktor pembanding seperti variabel biaya proyek dalam memperhitungkan total durasi proyek.

- Penelitian - penelitian berikut diharapkan memasukkan faktor keterbatasan kelompok kerja, sehingga dapat menghasilkan penjadwalan LSM yang lebih realistis.

- Pengembangan penelitian berikut hendaknya mempertimbangkan urutan penugasan kelompok kerja untuk mengerjakan unit aktivitas yang berulang (construction order). 


\section{DAFTAR REFERENSI}

Agrama, F. A. E.-M. (2011). "Linear Projects Scheduling Using Spreadsheets Features" Alexandria Engineering Journal, 50(2), 179-185. http://doi.org/10.1016/j.aej.2011.01.018

Ammar, M. A. (2013). "LOB and CPM Integrated Method for Scheduling Repetitive Projects" Journal of Construction Engineering and Management.

Arditi, D., Tokdemir, O. B., \& Suh, K. (2002). "Challenges in Line-of-Balance Scheduling" Journal of Construction Engineering and Management. http://doi.org/10.1061/(ASCE)0733-9364(2002)128:6(545)

Hafez, S. M. (2004). "Practical Limitations of Line-of-Balance in Scheduling Repetitive Construction Units" Alexandria Engineering Joumal, 43(5), 653-661. Retrieved from http://www.scopus.com/inward/record.url?eid=2-s2.

014644404875\&partnerlD=40\&md5=5dbdf585113df5d4892d03f17533c98c

Hyari, K., \& El-Rayes, K. (2006). "Optimal Planning and Scheduling for Repetitive Construction Projects" Joumal of Management in Engineering, 22(1), 11-19. http://doi.org/Doi 10.1061/(Asce)0742-597x(2006)22:1(11)

Iswanto, N. (2006). Sistem Penjadwalan LSM untuk Proyek Instalasi Pipa Bawah Tanah. Universitas Kristen Petra.

Shuh, J., Lin, Y.-H., Lin, Y.-C., \& Wang, L.-C. (2013). "Simplified CPM/LOB Methodology for Construction Project Management" Hokkaido University Collection of Scholarly and Academic Paper. Retrieved from http://hdl.handle.net/2115/54211

Zolfaghar Dolabi, H. R., Afshar, A., \& Abbasnia, R. (2014). "CPM/LOB Scheduling Method for Project Deadline Constraint Satisfaction" Automation in Construction, 48, 107-118. http://doi.org/10.1016/j.autcon.2014.09.003 